\title{
GERAKAN REVIVALISME ISLAM DAN WACANA PENERAPAN SYARIAH DI INDONESIA: \\ Telaah Pengalaman PKS dan Salafi
}

\author{
Moh. Nurhaß̧im \\ Fakultas Agama Islam (FAI) UMM, Telp. 0811366476 \\ email: nurhakimenator@gmail.com.
}

\begin{abstract}
This essay tries to critically evaluate a way of thinking developed among Salafi leader dan PKS as a movement of Islamic revivalism which related to the implementation of Islamic law (syari'ah) into the Indonesian democracy conteks. There are a number of critical notes was discovered from literary researches and interviews with several leader of the movement. firstly, Basicly both PKS and Salafi leader longing for the implementation of Islamic law in the Indonesian democracy context. Despite the fact that PKS tend to act disparagingly toward democracy, while Salafi clearly repudiate democracy system, however, both of this group agree to "manipulate" this system to strugle for the embodiment of Islamic law with different startgies and substance. Secondly, PKS enters this system while trying to "objectify" Islamic values through preaching dan politics (structurally and culturally). In the same vein, Salafi manipulates democracy to strenghthen their ideological basis and their Islamic puritans awareness through preaching. Regarding politics, Salafi tends to be "pasive". Lastly, there are indications that the idea of the Islamic law implementation among PKS leader has dynamically changed following the politics dynamics. This often percieved as an inconsistency by the society. Meanwhile, the idea and efforts to implement Islamic law among Salafi leader is limited to the area of family rule and rarely about public rules. The result of this critical evaluation upon the implementation of Islamic law done by PKS and Salafi leaders, up to this point, have not provide a viable recomendation as an ideal model of strengthening democracy system and implementing Islamic law in Indonesia.
\end{abstract}


Tulisan ini berusaha menelaah secara kritis pemikiran yang berkembang di kalangan para tokoh Salafi dan PKS sebagai gerakan revivalisme Islam berkenaan dengan wacana penerapan syariah dalam konteks demokratisasi di Indonesia. Berdasarkan kajian pustaka dan wawancara terhadap sejumlah tokoh gerakan ini ditemukan beberapa catatan kritis. Pertama, baik PKS maupun Salafi pada prinsipnya sama-sama menginginkan penerapan syariah Islam di Indonesia dalam konteks alam demokrasi. Meskipun PKS bersikap kritis, sementara Salafi menolak sistem demokrasi, namun keduanya "memanfaatkan" sistem ini untuk memperjuangkan cita-cita penerapan syariah dengan pemaknaan dan strategi yang berbeda. Kedua, PKS memasuki sistem tersebut dan berupaya melakukan "objektivikasi" nilai-nilai Islam melalui jalur dakwah dan politik (struktur dan kultur). Sedangkan Salafi, memanfaatkan suasana alam demokrasi untuk memperkuat basis ideologis dan kesadaran Islam puritan pada umat melalui jalur dakwah, dan bersikap "pasif" terhadap politik. Kedua, terdapat indikator bahwa wacana penerapan syariah di kalangan para tokoh PKS mengalami perubahan terus menerus seiring dinamika politik, sehingga tak jarang dikesankan umum inkonsisten. Sementara, ide dan upaya penerapan syariah di kalangan tokoh Salafi terbatas pada wilayah hukum keluarga, dan sangat terbatas dalam wilayah hukum publik. Penilaian kritis dapat dilakukan bahwa wacana penerapan syariah yang dibangkitkan oleh kedua gerakan sampai batas ini belum menunjukkan sebuah model yang jelas dan dapat direkomendasikan sebagai bentuk hubungan ideal antara tendensi penguatan sistem demokrasi dengan tendensi wacana penerapan syariah di Indonesia.

Kata Kunci: gerakan revivalisme, PKS, Salafi, penerapan syariah, demokrasi.

\section{Pendahuluan}

Pasca jatuh rejim Suharto muncul dan berkembang pesat gerakangerakan Islam seperti jamur di musim hujan. Di antara gerakan-gerakan itu adalah Tarbiyah yang kemudian menjadi Partai Keadilan Sejahtera (PKS), Hizbut Tahrir Indonesia (HTI), Majlis Mujahidin Indonesia (MMI), Front Pembela Islam (FPI), Laskar Jihad, Salafi, Jama'ah Tabligh, dan kelompokkelompok sempalan (splinter group) yang lain. Gerakan-gerakan ini muncul secara fenomenal dan kontroversial. Fenomenal, karena ia berkembang secara amat cepat dan menarik perhatian banyak pihak. Mereka berhasil mendirikan cabang-cabang, dan mendapatkan pengikut serta simpatisan yang cukup signifikan. Kontroversial, karena ia menimbulkan pro-kontra, berbagai pertanyaan, dan perasaan khawatir pada sehagian besar masyarakat, tetapi pada saat yang sama menjadi harapan bagi sebagian yang lain.

Pro-kontra itu bisa dipahami oleh karena di antara gerakan-gerakan ini ada yang cenderung bersikap radikal, militan, bahkan sebagian menggunakan 
kekerasan. Namun, di sisi lain, di antara gerakan-gerakan ada yang bersikap moderat, simpatik, dan memberikan pelayanan-pelayanan publik. Selain itu, pro-kontra disebabkan oleh faktor-faktor lain seperti persaingan politik ataupun kepentingan dan boleh jadi dikarenakan sebagian banyak kalangan masyarakat belum cukup mengenali mereka yang sebenarnya.

Gerakan-gerakan ini antara lain memberikan kritik tajam kepada pemerintah yang dinilai gagal mengembangkan politik, ekonomi, hukum, pendidikan, budaya dan keamanan. Mereka kecewa terhadap praktik demokrasi yang ditampilkan oleh pemerintahan Orde Baru dan Orde Lama yang bersikap diktaktor, dan meminggirkan umat Islam. Mereka menilai bahwa sistem demokrasi yang dianut selama ini mesti dilihat kembali secara kritis. Bahkan, di antara mereka seperti HTI dan MMI menolak sistem ini, karena dianggap bertentangan dengan Islam dan penyebab krisis multidimensional di Indonesia. Selain memberikan respon terhadap pemerintah, gerakan-gerakan itu juga merespon isu-isu internasional. Mereka menyampaikan "ancaman-ancaman" terhadap negara-negara yang dianggap menciptakan problem berkepanjangan di kawasan Timur Tengah khususnya Palestina. Untuk itu, mereka mengajak umat Islam bersatu, mencari sebab-sebab kemunduran, meningkatkan dan mengembangkan diri, serta menyerukan kebangkitan umat Islam.

Untuk merespon problem internal Indonesia, gerakan-gerakan revivalisme memajukan Islam sebagai solusi. Salah satu caranya adalah berupaya menerapkan syariah Islam ke dalam seluruh aspek kehidupan: negara, politik, ekonomi, pendidikan, budaya, dan sosial. Isu penerapan syariah Islam ini mereka bangkitkan terutama sejak masa jatuh Soeharto hingga sekarang, atau masa yang biasa disebut "era reformasi". Jika gerakan-gerakan, organisasiorganisasi, dan partai-partai politik selainnya menolak wacana formalisasi syariah di Indonesia, maka gerakan revivalisme justru mewacanakannya, bahkan telah melakukan upaya-upaya lebih jauh seperti menyusun rancangan konstitusi Islami, mendirikan komite-komite khusus syariah, dan melakukan aktivitas-aktivitas penyadaran masyarakat akan pentingnya syariah. Sehingga, pada masa yang sama, muncul proses-proses legislasi syariah Islam ke dalam Undang-Undang serta Peraturan-Peraturan di berbagai daerah seperti di Aceh, Banten, Cianjur (Jawa Barat), Pamekasan (Madura), Makassar (Rosyadi, dkk, 2006:159-198).

Ide penerapan syariah Islam menimbulkan kontroversi (pro-kontra) di kalangan masyarakat umum, gerakan-gerakan Islam, organisasi-organisasi sosial, partai-partai politik, pihak legislatif dan pihak eksekutif sejak masa 
sebelum kemerdekaan hingga saat ini. Pada masa menjelang kemerdekaan Indonesia kontroversi terjadi antara kelompok Islam dengan kelompok nasional sekuler tentang asas negara, sehingga melahirkan Piagam Jakarta sebagai hasil kompromi. Tetapi, setelah proklamasi kemerdekaan pada 1945, melalui musyawarah Panitia Persiapan Kemerdekaan Indonesia (PPKI), tujuh kata dalam Piagam Jakarta (Ketuhanan dengan kewajiaban menjalankan syariat Islam bagi pemeluk-pemeluknya) dibatalkan. Pada tahun 1955 tuntutan untuk mengembalikan tujuh kata yang dihilangkan di atas dibangkitkan kembali pada sidang parlemen. Dan, pada masa reformasi sekarang khususnya menjelang Pilihan Raya 1999 dan 2004 yang lalu tuntutan penerapan Syariah dibangkitkan kembali oleh partai-partai Islam dan di dukung oleh gerakan-gerakan Islam revivalis sebagaimana dijelaskan di atas (alJufri, 2004:7-10)

Meskipun ide dan perjuangan bagi penerapan syariah Islam di Indonesia telah lama ada sejak negara ini didirikan hingga sekarang yang dilakukan oleh organisasi-organisasi, gerakan-gerakan, dan partai-partai politik, namun ia mempunyai kekhususan dibanding dengan ide-ide yang sebelumnya muncul. Oleh karena, ide ini dibangkitkan pada konteks sosial, politik, budaya masyarakat Indonesia yang berbeda, yaitu era reformasi. Selain itu, tuntutan penerapan Syariat pada masa ini sangatlah dimungkinkan terkait dengan isu-isu dunia Islam kontemporer seperti apa yang biasa disebut dengan revivalisme Islam. Tulisan ini berusaha menjelaskan wacana penerapan syariah yang dibangkitkan oleh para tokoh PKS dan Salafi dalam konteks alam demokratisasi yang sedang berlangsung di tanah air.

\section{Revivalisme dan Upaya Penerapan Syariah}

Gerakan-gerakan sebagaimana dijelaskan di atas dalam kajian ilmiah dapat disebut gerakan-gerakan revivalisme Islam. Kata revivalisme dari segi bahasa diderevasikan dari kata "revival" yang berarti "kebangkitan kembali" atau "kebangunan baru". Sedangkan kata "revivalis" berarti orang atau kelompok yang mengalami kebangkitan kembali dari keadaan semula yang statis. Ini semakna dengan kata resurgence dan kata awakening (kebangunan atau kesadaran)". Kata revival (kebangkitan kembali) berarti suatu upaya menghidupkan kembali perasaan keagamaan, sedangkan kata reform (pembaharuan) adalah upaya memberikan bentuk baru. Pendukung kedua gerakan itu disebut dengan, yang pertama revivalis, dan yang kedua reformis". Menurut Fazlur Rahman, revivalisme Islam (pramodern) adalah gerakan semisal Wahabi, sementara neo-revivalisme adalah gerakan semisal Ikhwanul 
Muslimin. Istilah ini juga dipergunakan oleh Yusuf Qardlawi dengan sebutan "alsakhwah allslamiyyah" sebagai pengganti istilah fundamentalisme yang dinilai kurang tepat dipergunakan (Esposito, 1990: 35).

Lebih lanjut, Esposito (1990:44) mendefinisikan "revival" dengan kebangkitan kembali; atau ikhtiar menghidupkan kembali perasaan keagamaan. Dalam buku yang lain, beliau menambahkan maksud itu dengan menuliskan.

"at the heart of the revivalist movements lies the quest for authenticity, identity and tradition." ...."Islamic revivalism is not theoretically and politically a unified movement. In fact, there are significant differences among the Islamist groups on many basic issues. Although revivalist movements seek to return to the basic or fundamental truths of their religion, revivalism is not a monolithic, unified and coherent movement, and there is no single strategy for the pursuit of its goals. There is no precedent for Muslims from different sects uniting under the banner of Islam, of Jihad, of anything, to form a political military phalanx".

Jika dilihat dari sisi ideologi, gerakan revivalisme pada umumnya memperjuangkan ide-ide yang diyakini meliputi: (1) Islam adalah agama dan negara (aldin wa aldaulah); (2) Islam agama menyeluruh, totalitas dan universal; (3) Kembali kepada Islam yang sebenarnya, yaitu al Quran dan al Sunnah; (4) Mengidealkan masa depan masyarakat, negara dan peradaban dalam kerangka Syariah Islam. Di dalam memahami Islam, gerakan revivalisme menggunakan pendekatan tekstual, literalskriptualistik. Sementara tujuan umum gerakan ini seperti dituturkan berikut (Said, 2000:182-184).

"The common objectives of the Islamic revival movement are: (1) Application of Shari'ah rules, principles and values in Muslim societies and their public institutions; (2) development of socio-economic and political system which would reflect Islamic principles and Shari'ah; (3) promotion of cultural identity basic on Islamic principles and heritage which would confirm historical continuity and represent a defensive response to the alienation which is associated with Western cultural domination; (4) promotion of Islamic moral values in everyday life, behavior or social interaction at both the individual and the collective levels; (5) production of socio-economic model of development, independent from Western industrial control, sensitive to national culture and responsive to actual local needs. This is a model that stems from the historical and objective conditions of Arab and Muslim societies; (6) promotion of Arab unity as a pre-condition for a wider Islamic unity based on the common shared historical Islamic values, Shari'ah principles and shared interests; (7) revival of Islamic civilization as a model with a universal message so that the Arab and Muslim world may gain its international status". 
Untuk merespon problem-problem internal Indonesia, gerakan-gerakan revivalisme mengidealkan Islam sebagai solusi. Salah satu pendekatannya adalah mengupayakan penerapan syariah Islam ke dalam seluruh aspek kehidupan: negara, politik, ekonomi, pendidikan, budaya, sosial, keluarga, dan lain-lain. Upaya ini mereka tawarkan terutama menjelang Pemilu 2004 dan sebetulnya jauh sebelumnya. Bahkan, setelah Pemilu mereka melakukan upaya-upaya formalisasi Syariah seperti mendirikan komite-komite khusus syariah, dan melegislasikan syariah Islam ke dalam Undang-Undang serta Peraturan-Peraturan di berbagai daerah seperti di Aceh, Banten, Cianjur (Jawa Barat), Pamekasan (Madura), Makassar (Rosyadi, dkk, 2006:159-198)

Dari sudut historis, sebenarnya upaya penerapan syariah Islam menimbulkan kontroversi (pro-kontra) di kalangan masyarakat luas, gerakan-gerakan Islam, organisasi-organisasi sosial, partai-partai politik, parlemen dan pihak ekskutif sejak masa sebelum kemerdekaan hingga saat ini. Pada masa menjelang kemerdekaan Indonesia kontroversi terjadi antara kelompok Islam dengan kelompok nasional sekuler tentang asas negara, sehingga melahirkan Piagam Jakarta sebagai hasil kompromi. Tetapi, setelah proklamasi kemerdekaan pada 1945, melalui musyawarah Panitia Persiapan Kemerdekaan Indonesia (PPKI), tujuh kata dalam Piagam Jakarta (Ketuhanan dengan kewajiaban menjalankan syariat Islam bagi pemeluk-pemeluknya) dibatalkan. Pada tahun 1955 tuntutan untuk mengembalikan tujuh kata yang dihilangkan di atas dibangkitkan kembali pada sidang parlemen (alJufri, 2004: 7-10). Dan, pada masa reformasi ini khususnya menjelang Pemilu 1999 dan 2004 tuntutan penerapan Syariah dibangkitkan kembali oleh partai-partai Islam dan didukung oleh gerakangerakan revivalisme sebagaimana dijelaskan di atas.

Bagi pendukungnya, upaya ini difahami sebagai satu-satunya jalan untuk menyelesaikan problem-problem Indonesia, bahkan problem dunia. Namun, bagi penentangnya, upaya ini dicurigai akan menimbulkan ketegangan sosial (social tension) dan konflik-konflik etnik yang pada gilirannya mengancam integritas bangsa Indonesia. Masing-masing pihak mengajukan argumen-argumen, bahkan tidak jarang menimbulkan ketegangan, konflik dan kekerasan fisik. Meskipun upaya penerapan syariah Islam di Indonesia telah lama ada, dan selalu mengalami kegagalan, namun upaya yang sama dibangkitkan kembali oleh gerakan-gerakan revivalisme kontemporer. Tampaknya, upaya ini mempunyai kekhususan dibanding dengan upaya-upaya sebelumnya mengingat ide ini dibangkitkan pada konteks sosial, politik, budaya masyarakat Indonesia yang berada dalam proses demokratisasi. Selain itu, tuntutan penerapan syariah 
pada masa ini terkait dengan isu-isu dunia Islam kontemporer seperti apa yang biasa mereka sebut dengan "kebangkitan Islam". Permasalahan yang perlu dijawab adalah mungkinkah menemukan relevansi penerapan syariah Islam terhadap proses demokratisasi di Indonesia pada era reformasi.

\section{Akar-Akar Ideologis Revivalisme}

Sebenarnya gerakan-gerakan revivalisme Islam kontemporer berakar pada gerakan revivalisme yang lahir abad ke-18 seperti Wahabi di Arab Saudi, al Sanusiyah di Afrika Utara, al Mahdi di Sudan, dan al Dihlawi di India. Mereka ini mengambil jalur pemikiran para tokoh ulama Salaf seperti Ibnu Taymiyah dan tokoh sebelumnya Imam Ahmad bin Hambal yang berhasil pempertahankan akidah Salaf al Shalih (para sahabat dan tabi'in).

Pada pertengahan abad ke-20 pemikiran ini kemudian disempurnakan menjadi suatu ideologi revivalisme oleh tokoh-tokoh sepertil Hassan al Banna dan Sayyid Qutb dari Ikhwanul Muslimin di Mesir dan Abul A'la al Maududi pendiri Jemaah Islam di Pakistan. Sampai pada batas perkembangan ini, akhirnya gerakan revivalisme terbelah menjadi dua. Pertama, disebut revivalismeharaki yang cenderung bersikap politis dan terorganisir yang menerima demokrasi seperti Ikhwanul Muslimin. Kedua, disebut revivalisme-da'awi yang bersifat nonpolitis, tak terorganisir dan mengedepankan kegiatan purifikasi ajaran Islam yang belakangan dikenal para tokohnya seperti Abd al Aziz bin Baz dan Nashirudin al Albani. Selanjutnya, dalam batas perkembangan kontemporer, revivalisme haraki memberikan inspirasi ideologis kepada gerakan semacam PKS di Indonesia, Partai Refah kemudian Keadilan di Turki, dan FIS di Aljazair. Sedangkan revivalisme da'awi diikuti belakangan oleh para tokoh Salafi di Indonesia yang muncul sekitar tahun '80-an. Namun, dasar ideologi revivalisme abad ke-18 yang dipelopori Wahabi itu dijadikan salah satu paradigma pembaruan Islam oleh kelompok modernis abad ke-19 seperti al Afghani, Mohammad Abduh, Ahmad Khan, Mohammad Iqbal, dan termasuk Ahmad Dahlan (dari sisi tertentu). Dasar ideologi yang terpenting adalah akidah Islam yang dijamin orsinalitasnya, prinsip free will (qadariyah), dan dibuka pintu ijtihad (Bubalo, 2007: 30).

Maka, dari sinilah muncul benih-benih apa yang sekarang disebut Islam liberal dan Islam radikal. Dan, disinilah letak kedua gerakan ini, seperti disebutkan di atas, terlahir dari akar revivalisme posmodern. Hanya saja, Islam liberal mengembangkan dasar-dasar revivalisme menjadi daya modernisasi dunia Islam yang berbau Barat (western), sedangkan Islam revivalis mengembangkannya 
menjadi kekuatan perlawanan terhadap modernisasi dalam arti westernisasi (pembaratan). Benih ideologi Islam liberal pada abad ke-20 dipelopori oleh murid-murid Mohammad Abduh seperti Ali Abd al Raziq dan Thaha Hussein. Sedangkan benih ideologi Islam radikal lahir dari ideologi Hassan al Banna dan, belakangan Sayyid Qutb (meskipun al Banna harus diakui lebih bersifat moderat daripada Sayyid Qutb). Rasyid Ridla, adalah murid Mohammad Abduh yang bersikap moderat di antara kedua gerakan ini, tetap setia menjaga mata rantai revivalisme atau salafisme sebelumnya.

Di Indonesia, gerakan revivalisme Islam yang mengambil bentuk radikal dimulai dari tokoh-tokoh revivalis Sumatera di abad ke-19 seperti Tuanku Nan Renceh, Haji Miskin, Haji Sumanik dan Haji Piobang. Khususnya, menurut suatu penelitian, ketiga yang terakhir mendapatkan pengaruh dari ideologi Wahabi. Mereka mendirikan semacam Dewan Revolusi yang dikenal dengan Harimau nan Salapan yang bertujuan menegakkan hukum syara dan membasmi kemaksiatan serta praktik-praktik syirik secara radikal seperti menyabung ayam, judi, makan sirih, dan membuka aurat bagi perempuan. Kelompok inilah yang kemudian dikenal dengan Kaum Paderi yang dipelopori oleh Tuanku Imam Bonjol yang mengobarkan perlawanan dan peperangan terhadap Belanda yang mendukung Kaum Adat penentang Kaum Paderi (Nurhakim, 1998: 97).

Di masa pasca kemerdekaan kelompok ini sesekali muncul sebagai bentuk perlawanan terhadap tindakan pemerintah yang represif terhadap gerakan-gerakan dakwah Islam. Sebagian bentuk kelompok ini seperti gerakan yang dipelopori oleh Kartosuwiryo yang didaulat oleh pengikutnya sebagai Imam Negara Islam yang bertujuan mendirikan Negara Islam. Selain itu, lahir Komando Jihad (Komji) pada tahun 1970-an, dan di awal dekade 1980an muncul tokoh yang menamakan diri Dr. Zulfikar. Tokoh ini mendirikan Dewan Zulfikar dan menggunakan bulletin AlHaqq untuk menyuarakan propaganda menegakkan hukum Allah, dan melawan pemerintah dan hukun thaghut yang diberlakukan.

Kemunculan kelompok revivalisme Islam yang radikal belakangan ini semakin menggejala dan banyak diperbincangkan. Hal ini tidak dapat dilepaskan dari sebab-sebab sosial politik, kultural, dan karena keberadaan gerakan-gerakan Islam yang ada selama ini dianggap mengalami "ortodoksi”. Sebagai contoh, munculnya Laskar Jihad dan Front Pembela Islam (FPI) sebagai respon dari ketidakberdayaan masyarakat, termasuk gerakan Islam pada umumnya, menangani berbagai bentuk pelanggaran moral sosial. 
Pada gerakan revivalisme tersebut, sebagian tokoh-tokohnya terdiri dari beberapa bentuk sempalan dari mainstream organisasi besar dan mapan baik Muhammadiyah maupun NU ataupun yang lain. Bisa saja secara idiologis sama, tetapi pilihan bidang garapan yang ditekankan berbeda-beda dari organisasi mainstream. Kelompok-kelompok yang tergabung didalamnya senantiasa menggunakan ideologi revivalisme, dan sama sekali menentang ideologi liberal atau modernis. Sayangnya, kebanyakan kita hanya bisa melihat dari luar dan gagal memahami "perasaan" yang sebenarnya.

\section{Faktor-Faktor Kemunculan Revivalisme Kontemporer}

Faktor penyebab kemunculan gerakan revivalisme Islam ada 4 yaitu, (1) kegagalan elite nasionalis sekuler; (2) ketiadaan partisipasi publik terhadap politik; (3) kekayaan melimpah dan kesenjangan ekonomi; (4) erosi kebudayaan. Sementara Juergensmeyer melihat bahwa gerakan ini merupakan nasionalisme religius yang kecewa terhadap kegagalan negara nasionalis sekuler (Zaki, 2008:23). Sedangkan Bassam Tibi melihatnya sebagai suatu bentuk respons terhadap berbagai problem berkaitan dengan ekses globalisasi dan fragmentasi. Adapun Ted Robert Gurr (Zaki, 2008: 34) menilai bahwa gerakan-gerakan ini lahir karena adanya kesenjangan antara harapan dan realitas berkenaan status dan materi. Kondisi ini, menurutnya, pada gilirannya akan menimbulkan rasa tidak sabar dan frustasi masyarakat terhadap berbagai kegagalan politik konvensional. Inilah yang ia sebut dengan faktor deprivasi sosial atau perasaan tertingggal.

Melihat beberapa faktor di atas dapat disimpulkan bahwa kemunculan kembali gerakan-gerakan revivalisme kontemporer lebih disebabkan oleh faktor kegagalan politik pemerintahan sekuler dan kesenjangan baik ekonomi, sosial dan budaya yang banyak terjadi di negara-negara berpenduduk mayoritas Muslim. Barangkali munculnya gerakan revivalisme Islam di Indonesia di era reformasi dapat dijelaskan melalui kerangka di atas. (1) Kegagalan baik orde lama maupun orde baru membawa bangsa Indonesia sejahtera; (2) Semakin jauh kesenjangan sosial, ekonomi dan pendidikan yang menjadikan umat Islam merasa semakin tertinggal dari yang lain. Tetapi, masih perlu ditambahkan di sini faktor-faktor eksternal, seperti konflik dan peperangan yang tak berkesudahan di negara-negara Muslim khususnya Palestina.

\section{Wacana Penerapan Syariah: Pengalaman PKS dan Salafi}

Berdasarkan beberapa batasan dan kategori di atas, maka kelompok- 
kelompok atau gerakan-gerakan baru yang dapat dimasukkan ke dalam kategori revivalisme kontemporer yang mengupayakan penerapan syariah Islam adalah PKS, Salafi, Hizbut Tahrir Indonesia (HTI), Majlis Mujahidin Indonesia (MMI), Negara Islam Indonesia (NII), dan Front Pembela Islam.

Namun demikian, karena perlunya pembatasan, dalam kesempatan ini hanya akan dibahas kasus PKS dan Salafi. PKS merupakan representasi upaya formalisasi syariah melalui jalur politik dan dakwah, sedangkan Salafi jalur dakwah, non-politik. Keduanya sama-sama memilih jalur damai, menghindari kerkerasan, dan menerima sistem demokrasi sebagai realitas, meskipun dalam perspektif keagamaan masih perlu dikritisi menurut PKS, dan ditolak menurut Salafi karena merupakan sistem di luar Islam. Lebih lanjut akan diuraikan pokok-pokok pemikiran dan gerakan formalisasi syariah dari masih-masing gerakan.

\section{PKS}

Mengawali pembicaraan tentang PKS, barangkali perlu direnungkan catatan salah seorang peneliti Australia, Greg (Bubalo, dkk., 2007:30) yang menyatakan bahwa PKS memiliki gaya tarik tersendiri karena menawarkan pendekatan baru dalam berpolitik. Hal ini lebih disebabkan karena, (1) mengambil sumber inspirasi ideologi dan organisasi dari Ikhwanul Muslimin di Mesir; (2) satu-satunya partai kader yang murni dalam politik Indonesia saat ini; (3) satu-satunya partai yang memiliki jaringan pelayanan sosial yang luas dan efektif; (4) menjadikan moralitas dalam kehidupan publik sebagai program utama politik; dan (5) partai yang sangat serius tentang masalah ideologi dan kebijakan dibanding partai-partai besar yang lain (Machmudi, 2005:5-7);

Pertama, sebagai gerakan revivalisme PKS berpandangan bahwa (1) Islam adalah agama dan negara (aldin wa aldaulah); (2) Islam agama menyeluruh, totalitas dan universal; (3) Kembali kepada Islam yang sebenarnya, yaitu al Quran dan al Sunnah; (4) Mengidealkan masa depan masyarakat, negara dan peradaban dalam kerangka Syariah Islam.

Kedua, Syariah difahami sebagai keseluruhan alIslam yang meliputi bidang akidah, ibadah, muamalah, akhlak, dan jinazah (hudud). Kesemua bidang ini harus diterapkan dalam kehidupan baik individu, keluarga, masyarakat, dan negara. Namun, penerapannya menggunakan prinsip-prinsip organisasi, pentahapan, fleksibelitas, dan jalan tengah (wasty). Dengan demikian, umumnya kader PKS tetap berpandangan bahwa hudud diterapkan apabila 
perangkat-perangkat pendukungnya telah terpenuhi, misalnya negara, hukum dan kondisi ekonomi masyarakat. Meskipun demikian, dalam kenyataan politik hal ini tidak pernah diwacanakan sebagaimana gerakan yang lain seperti HTI dan MMI.

Ketiga, pentahapan penerapan syariah dimulai dari penyadaran diri sendiri, keluarga, masyarakat, dan baru negara. Menggunakan jalur dakwah dan politik, atau dalam terminologi lain, melalui jalur kultural dan struktural. Oleh karenanya, PKS menerima upaya formalisasi syariah melaui proses konstitusi dan legislasi, meskipun dalam kenyataan strategi ini belakangan kurang begitu gencar disuarakan seperti di masa-masa perkembangan awal PKS.

Keempat, dalam hal demokrasi dan masalah-masalah yang timbul darinya sekitar HAM, pluralisme dan gender, PKS lebih adaptif dibanding gerakangerakan revivalisme yang lain. Ini bisa dilihat, misalnya pada visi Indonesia yang dicita-citakan: Terwujudnya masyarakat madani yang adil, sejahtera, dan bermartabat (Tim PKS, 2007).

Kelima, dalam memahami teks dan realitas, PKS berbeda dengan Salafi atau gerakan revivalisme radikal yang lain yang cenderung tekstual. Berdasarkan perkembangan terakhir, mulai mempertimbangkan pendekatan-pendekatan kontekstual dan objektifikasi.

\section{Salafi}

Fenomena Salafi sebagai gerakan dakwah di Indonesia mulai dikenal sekitar tahun '80-an yaitu, sekelompok para da'i atau ustazd yang berupaya keras menerapkan manhaj Salaf alShalih. Kebanyakan mereka adalah lulusan LIPIA Jakarta dan beberapa perguruan atau ma'had di Saudi Arabia, Yordania dan Yaman. Mereka menyebarkan dakwah di tengah-tengah masyarakat, pondok pesantren dan kampus-kampus melalui forum pengajian-pengajian. Belakangan ini, peserta pengajian, pengikut dan simpatisan menunjukkan jumlah peningkatan.

Sebenarnya terdapat kesulitan menggolongkan kelompok ini ke dalam kategori gerakan dan organisasi sebagaimana difahami. Umumnya para pengikut dan tokoh-tokohnya mengklaim Salafi bukanlah organisasi. Salafi diakui sebagai kegiatan dakwah yang dilakukan oleh orang-orang yang mempunyai concern dengan pembangunan kembali Islam (Turmudi, dkk, 2005:157-158). Hanya saja dapat mencatat ada kecenderungan di antara sebagian terkecil tokoh-tokoh Salafi yang ingin mengorganisir diri, tetapi menimbulkan prokontra di dalam. Sebagian lagi ada yang menginginkan afiliasi politik, namun 
banyak yang menentang dari kalangan tokoh Salafi yang lain. Meski demikian banyak sekali mereka mendirikan yayasan, pondok pesantren, sekolah, dan media-media dakwah lain seperti buletin dan majalah.

Meski dalam prinsip Salafi mengklaim monolitik, tetapi dalam realitas dapat ditemui varian-varian. Pertama, Salafi yang berkecenderungan melakukan dakwah saja dalam pengertian terbatas. Kedua, Salafi yang berdakwah menggunakan media gerakan dan organisasi, bahkan memasuki wilayah politik. Ketiga, Salafi yang mengartikulasikan jihad sebagai perang, "teror" dan bersifat radikal. Walau bagaimanapun, konsentrasi gerakan Salafi pada dakwah dan purifikasi, serta menangani tema-tema tauhid. Kajian ini hanya akan membahas Salafi varian yang pertama.

Di antara tokoh-tokoh Salafi ini di Indonesia sekarang adalah Ustad. Abu Nida' Khamsaha (Mudir Ma'had Bin Baz Yogyakarta), Ustad Yazid Abdul Jawaz (Bogor), Ustad Ahmad Fais Asifuddin (Mudir Ma'had Imam Bukhari, Surakarta), Ustad Aunur Rafiq Ghufran (Mudir Ma'had al Furqan, Gresik), Ustad Yusuf Baisa (Mantan Mudir Ma'had alIrsyad, Tengaran, Semarang), Ustad Abdurrahman Al Tamimi (Mudir d/h Ma'had al Irsyad, Surabaya). (Masih banyak tokoh-tokoh Salafi yang belum disebutkan di sini).

Berkenaan dengan upaya penerapan syariah Islam di Indonesia, beberapa pandangan dan upaya dakwah yang dilakukan oleh tokoh-tokoh Salafi dapat diringkas sebagai berikut.

Pertama, Salafi memandang bahwa syariah Islam adalah agama Allah yang menyeluruh, tidak terbatas pada hukum-hukum (baca: fiqh) saja. Penerapan syariah tidak boleh parsial, tetapi haruslah keseluruhannya termasuk hudud.

Kedua, metode memahami syariah Islam haruslah terikat kepada manhaj (metodologi) al Shalafal Shalih, baik dalam akidah, ibadah, muamalah, akhlak, dan jinayah. Di antara pokok-pokok manhaj itu: (1) mendahulukan syariah daripada logika, (2) tidak mengenal ta'wil seperti yang dipergunakan kaum teolog (kalam); (3) berpegang pada bunyi al Quran dan al Hadits sebagaimana dipahami oleh al Salaf al Shalih, (Busyir, tt:124)

Ketiga, penerapan syariah menggunakan strategi tashfiyah wa tarbiyyah. Membersihkan pemahaman-pemahaman dan pelaksanaan ajaran yang salah, seperti bid'ah dan kemusyrikan. Kemudian, menyampaikan ajaran-ajaran Islam yang benar dan murni, lalu mempraktekkannya dalam semua aspek kehidupan. Dimulai dari individu, keluarga, masyarakat, dan kemudian negara.

Keempat, secara prinsip menolak sistem demokrasi seperti yang ada, serta peraturan-peraturan yang berlaku di luar syariah Islam sebagaimana dipahami 
oleh salafi. Mereka menolak sistem parlemen, cara pemilihan umum, dan cara berdemontrasi seperti yang ada sekarang. Tetapi, dalam realitas mereka memilih "pasif',dan tidak ikut campur dalam halhal yang secara prinsip ditolak. Namun, mereka tidak memilih perlawanan secara fisik sebagai jalan amar ma'ruf nahi munkar.

Demikian pokok-pokok pandangan dan upaya formalisasi syariah menurut PKS dan Salafi.

\section{Simpulan}

Dalam konteks negara demokrasi, keberadaan gerakan-gerakan revivalisme Islam kontemporer seperti pengalaman PKS dan Salafi dapat dijelaskan sebagai berikut.

Pertama, baik PKS maupun Salafi sama-sama mengusung ide-ide penerapan syariah Islam di Indonesia dalam konteks demokrasi. Meski bersikap kritis bahkan menolak secara prinsip terhadap sistem demokrasi, namun keduanya memanfaatkan sistem ini untuk memperjuangkan cita-cita penerapan syariah dengan strategi yang berbeda. PKS memasuki sistem tersebut dan berupaya melakukan "objektifikasi” nilai-nilai Islam ke dalam lokus Indonesia melalui jalur dakwah dan politik. Sedangkan Salafi, memanfaatkan suasana demokrasi untuk memperkuat basis ideologis dan kesadaran Islam pada umat melalui dakwah, dan bersikap "pasif" terhadap politik.

Kedua, terdapat indikator bahwa upaya formalisasi syariah Islam di PKS mengalami dinamika pemaknaan dan intensitas pewacanaan sejalan dengan dinamika politik di tanah air. Hal ini menunjukkan bahwa ide penerapan syariah Islam dalam konteks politik di tanah air perlu diuji otentisitas dan relevansinya. Sementara, ide dan upaya penerapan syariah di kalangan tokoh Salafi sebenarnya dapat dikatakan sebatas pada wilayah-wilayah hukum keluarga. Sedikitpun tidak memasuki wilayah hukum pablik.

Ketiga, sampai saat ini kedua gerakan sama-sama ingin menempatkan posisi yang tepat terhadap proses demokratisasi. Keduanya, khususnya PKS ditantang untuk membuktikan platform sebagai partai yang bersih, peduli dan profesional ketika sebagian kader telah memenangkan Pilkada di beberapa daerah. Sementara, Salafi sudah semestinya ikut menjaga komitmen untuk tidak merekomendasikan apapun dari bentuk kekerasan di negeri ini. 


\section{Daftar Pustaka}

Al Jufri. 2004. "Pengantar" dalam Bukhori Yusuf dan Imamm Santoso (Ed.), Penerapan Syariat Islam di Indonesia antara Peluang daan Tantangan. Jakarta: Pusat Konsultasi Syariah, hh. 7-10.

Basyir, Abu Umar. tt. Ada Apa dengan Salafi? Solo: Rumah Dzikir.

Bubalo, Anthony dan Fealy, Greg. 2007. Joining the Caravan?: The Middle East, Islamism and Indonesia. Terjemahan oleh Akh Muzakki, Bandung: Mizan, h. 30 .

Machmudi, Yon. 2005. Partai Keadilan Sejahtera Wajah Baru Politik Islam Indonesia. Bandung: Syamil Cipta Media.

Nurhakim, M. 1998. Islam Doktrin, Pemikiran dan Realitas Historis. Malang. UMM Press

Rosyadi, Rahmat dan Ahmad, Rais. 2006. Formalisasi Syariat Islam dalam Prespektif Tata Hukum Indonesia. Jakarta: Ghalia Indonesia, hh. 159-198.

Tim PKS. 2007. Platform Kebijakan Pembangunan Partai Keadilan Sejahtera. Jakarta: MPP-PKS.

Turmudi, Endang, dan Sihbudi, Riza. 2005. Islam dan Radikalisme di Indonesia. Jakarta: LIPI Press.

Walif Said dalam Muhammad, Mumtaz Ali, ed. 2000. Modern Islamic Movements Models Problems and Prospects. Kuala Lumpur:A.S. Noordeen, h. $182-$ 184.

Zaki Mubarok, M. 2008. Geneologi Islam Radikal di Indonesia Gerakan, Pemikiran dan Prospek Demokrasi, Jakarta.LP3ES. 